\title{
History of Design - Reflections
}

One year ago, after a meeting with Susan Yelavich at Parsons - The New School for Design in New York, I began an exchange of Letters on the History of Design in which numerous scholars took part. These Letters are published in the first issue of the online magazine of the Associazione Italiana degli Storici del Design (http//www.aisdesign.org): all of the citations here that are not mentioned in the footnotes come straight out of the Letters. History of Design's loss of influence today as an autonomous discipline as well as the loss it has undergone in the field of education lies at the heart of the debate. I believe it may be of benefit to carry on such a debate taking into account both the similarities that stand out as well as any noticeable differences.

We live in the third phase of the Industrial Revolution, one characterized by a clear discontinuity with the previous phase. This is nothing new: the second phase of the Industrial Revolution introduced a similar discontinuity with respect to the first. I am referring to the gap between the twentieth-century phases of both Fordism and the avant-garde and the nineteenth-century phase characterized by the clash between designers who sought to give form to advanced innovation and designers/artists who rejected industry, trains, the city (society) in the name of a return to craftsmanship and the community (gemeinschaft). In the current phase characterized by globalization and new technologies, we are witnessing a profound change in the role of design. Marc Bloch, the great historian who founded the Annales, proposed a "regressive" way of writing history in the sense that it should date back from the present (the present stimuli, discoveries, and sources) to the past: to study "the past in light of the present and the present in light of the past." (1) It is a point that today should be kept in mind when working on the history of design. However, let us now return to the topic under investigation: the following are some arguments that I consider relevant for a detailed analysis. 
1 - The situation today is that history has lost influence within the cultural debate. With regards to this, Victor Margolin refers to Hobsbawm, who in turn points out the tendency for "an a-historical, engineering, problem-solving approach" to prevail when writing history on a more general level. Some time before, Fredric Jameson (2) had already emphasized how "the weakening of historicity" or at least the demonstration of its irrationality was the main principle of the postmodern. Hal Foster (3) and many other authors have expressed similar views.

2 - Teaching history of design tends to become marginal, as the above mentioned Letters demonstrate. Therefore, minor attention is given to the problem concerning the training of historians of design, such as regarding a specific university-level framework (PhD's, Master's Degrees, etc.). Particularly, the history of design is seen "as a tool for better design... an approach I consider to be highly instrumentalist", as Kjetil Fallan writes. I agree with Fallan even though I believe that designers should be acquainted with the history of design rather than disregard it.

3 - The way of interpreting the history of design seems to be growing in different directions. I would like to quote two examples taken from the Letters: Kjetil Fallan and Clive Dilnot. Kjetil Fallan considers himself "a firm believer in the intrinsic value of historical studies" and hopes for a development in "design history as a solid academic endeavor, and if it is ever to make an impact on the broader field of history". On the other hand, Clive Dilnot believes that the reduced significance of the history of design is also "a result of the breakdown of the modern design project and the idea of the autonomous design discipline...". He claims, and in my view rightly so, that "relevant history would change its identity in many cases, focusing less on the autonomy of the discipline and more on the factors that now bear on these fields". However, here a clarification should be made: Dilnot believes that even with regards to "modern art", the idea of considering it an autonomous discipline is fading out as well. However, this does not seem to lead to the end of art history but at the very most allows for new keys of interpretation, unless we agree with Arthur C. Danto when he says that we are already, in Hegelian fashion, "After the End of Art". (4)

4 - Lastly, globalization has been giving rise to many debates, as witnessed both by XX Congress of Historical Sciences (Sydney 2005), which to a large extent has focused on issues dealing with the history of extra-European populations and many other international congresses on design. Above all, there have been debates on the concept of nation itself, criticized as "modern myth". This criticism brings many authors to prefer, with regards to the history of design, global narrations rather than those national. (5) However, this prevents us from analyzing our current situation; a number of nations that until not long ago were considered "void of history" are coming into being as States/Nations and are currently trying to both affirm, often in a conflictual way, and build, in a more or less mythical way, their identity. Secondly, New World History is developing today with the purpose of overcoming Eurocentrism while rejecting the nineteenth-century idea that "peoples without history" exist. Nations that have recently achieved their independence are claiming their own historical course and identity. They therefore reject the concept 
of design as being linked to the Industrial Revolution and push, instead, for a broader definition of design that includes the history of artifacts in general, material culture, and craftsmanship. All of this is influencing the international congresses on design. See among others the "Design and Craft" (ICDHS 2010) and "Design Dialects" (Istanbul 2013) conferences. It is obvious that this should be put in relation with other fields of study such as both "Cultural History", which puts much attention on material culture and everyday life, and "Material Culture Studies". Meanwhile, Victor Margolin is in the process of writing a history in three volumes where he rejects any terms referring to an a quo date and therefore any distinction between design and craftsmanship. I find particularly interesting how different kinds of studies, either based on history or Design Studies, are growing and producing a vast array of results valuable for our knowledge.

These topics are typical of our contemporary society, while an ever-present issue in the histories of design reflects what design is and how difficult it is to affix a definition to it. According to Margolin, it is this difficulty that both renders any discussion about the History of Design impossible and makes the study of Design necessary. Actually, something similar has happened in other disciplines. To give some examples: physicists place the birth of classical physics in the seventeenth century with the Scientific Revolution; chemists date the origin of modern chemistry back to the twentieth century. It is therefore a problem of periodizations. Even though the New World History is pushing for an abandonment of these periodizations, I believe that one cannot write history while immersing himself/herself in a time that is linear and not broken down into phases. Periodizations are without question suggestive since they are based on theoretical assumptions, but - as Krystzof Pomian writes - "they serve the purpose of turning facts into concepts". (6) As I have already observed, with regards to this way of thinking, any discussion about the History of Art would be impossible given the difficulty in defining what art is. The History of Art had to face historical phases with radically different notions of art. Take, for instance, the Greek notion of techne (art); the distinction made during the Middle Ages between liberal and servile arts (neither painting, nor sculpting, nor architecture, nor craftsmanship were considered part of the liberal arts, aka arts of the free-man); the assertion made by Leon Battista Alberti during the Renaissance that the artist is no longer a craftsman but an intellectual, a statement to which I will return briefly, that records and sets in motion that process of differentiation between arts and craftsmanship.

In light of these considerations, the subject I would like to propose is the following: rather than questioning when design originated, could it not be more useful to verify when the designer as a professional and social figure emerged? The answer is that such a figure gradually defined itself between the 18th and 19th centuries, when the professional figure of the engineer appeared (7), while the notion of Fine Arts was shaping itself and the Art Academies were beginning to develop. (8) Design in both architecture and applied arts developed between the 16th and 18th centuries, but, in any case, it still was descriptive/representative. It was only in the 18th century that things changed due to both the first phase of the Industrial Revolution and the development of new methods of representation which tended to take on a prescriptive approach in order to mitigate the superficiality of previous methods. 
During those years, the method of representation created by Gaspard Monge (17461818) established itself. This method, which at the beginning was kept as a secret and only known to the military for its purposes, spread widely under the name "descriptive geometry". Monge's Method is a representative technique that allows designers to pass on to the project manager all the necessary information in order to execute the project with precision. A new way of communicating between the designer and the producer is defined, making a distinction possible between designer and craftsman. Monge's book Géométrie Descriptive was translated into English in 1808. (9)

It was, in fact, in this phase that the need to train a new professional figure (aka the designer) with the express purpose of satisfying the growing firm's needs began to arise. In 1852 Henry Cole became Superintendent of the Department of Practical Art (formerly the London School of Design) where Gottfried Semper introduced Workshops on Materials and Art Botany was taught with the book by Owen Jones The Grammar of Ornament as a reference text. This is the beginning of a process that developed up until the time of the Bauhaus, with its Workshops, Grundkurs, and Basic Design. Establishing a school implies that there is a spectrum of knowledge that can be passed down that goes beyond learning in the workplace and thus creates a new professional figure, the designer.

Christopher Dresser, a collaborator of Jones who studied at the London School of Design, worked during the second half of the nineteenth century as a consultant, an artistic director and a designer. During his work life, he demonstrated a keen awareness of what the role of designer entailed. He firmly believed in the equality between the "Status" of the producer and that of the designer and, in fact, was the first designer to be allowed by the many industries he had worked for to sign the products next to the firm logo, a practice that would become more diffused years later.

The process of shaping and honing the figure of the designer as a socially recognized professional figure is long and complex. Here another issue arises. Today, in this new phase of the industrial revolution, sectors in which the designer has previously worked are multiplying. The idea of a unitary culture of the project is being replaced by one based on specialization, mainly one that is technical-managerial. (10) This is both a mirror and a manifestation of on-going changes and is indeed a declaration of how the need for both any form of reflection on the project and any theoretical-methodological approach is extinct. Thus, we return to the problem mentioned at the beginning: the need to reflect today on the role of the History of Design, as an autonomous discipline, one essential for training.

(1) M. Bloch, Apologie pour l'histoire ou Métier d'historien, Introduzione ai « Cahiers des Annales », Armand Colin, Paris 1949

(1) F. Jamieson, Postmodernism or the Cultural Logic of Late Capitalism, New Left Review 1984. 
(3) A.C. Danto, After the End of Art. Contemporary Art and the Pale of History, Board of Trustees of the National Gallery of Art, Washington D.C. 1997

(4) Cfr. K. Fallan, G. Lees Maffei, "Introduction: the History of Italian Design" in Made in Italy. Rethinking a Century of Italian Design, Bloomsbury Academic, London/New York 2014.

(5) K. Pomian, L'ordine del tempo, Einaudi, Torino 1992, p. 176)

(6) J. K. Finch, The story of Engineering, Anchor Books- Doubleday \& Co, New York 1960

(7) N. Pevsner, Academies of Art. Past and Present, Cambridge University Press, England 1940

(8) Snezana Lawrence, History of Descriptive Geometry in England, Proceedings of the First

International Congress on Construction History, Madrid January 2003

(9) Cfr. V.Pasca, "Design in futuro", in XXI Secolo. Gli spazi e le arti, Treccani 2010. 